\title{
Specific and Sensitive Nutrition Interventions with Nutritional Status of Toddlers as Prevention of Stunting in the Coronavirus Disease 2019 Pandemic in Sigi District, Indonesia
}

\author{
Putu Candriasih $^{1 *}$, Metrys Ndama ${ }^{2}$, Anna Veronica Pont ${ }^{3}$ \\ ${ }^{1}$ Department of Nutrition, Poltekkes Kemenkes Palu, Palu City, Central Sulawesi, Indonesia; ${ }^{2}$ Department of Nursing, Poltekkes \\ Kemenkes Palu, Palu City, Central Sulawesi, Indonesia; ${ }^{3}$ Department of Midwifery, Poltekkes Kemenkes Palu, Palu City, \\ Central Sulawesi, Indonesia
}

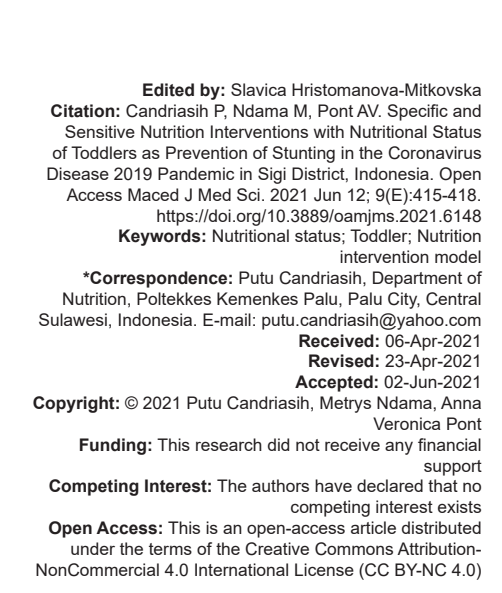

\begin{abstract}
AIM: The research objectives were to determine the specific and sensitive intervention model in stunting prevention efforts in the coronavirus disease 2019 (COVID-19) pandemic and also to determine the relationship between specific and sensitive interventions on children's nutritional status under five in the COVID-19 pandemic in stunting locus village.

METHODS: This type of research was an observational study with a cross-sectional approach. The population size is 35 families of short children under five and the sample size is 35 people with the sampling technique is total sampling This study used the Chi-square test with a significance level of $p<0.05$ with SPSS computer software.

RESULTS: Nutritional status based on the body weight/age index, $63 \%$ was very underweight and underweight. Based on body height/age, $28.6 \%$ was stunted. Based on body weight/body height, $17.1 \%$ was severe malnutrition and $40.0 \%$ was malnutrition. The results of the bivariate analysis for specific nutrition interventions with body weight/ age showed $p=0.98$, body weight/age had $p=0.668$, and body height/age had $p=0.968$, which indicated no significant relationship.

CONCLUSIONS: Sensitive nutrition intervention showed no relationship between sensitive intervention and children's nutritional status under five.
\end{abstract}

\section{Introduction}

The incidence of stunting under five is one of the nutritional problems experienced by children under five in the world today [1], [2]. Globally, nearly 200 million children under five are stunted, wasted, or both, and a minimal 340 million from hunger are hidden from deficiency of vitamins and minerals [3]. Nutritional problems account for $45 \%$ of child deaths under five. Investing in increased nutrition interventions would save 900 lives, reduce stunting by $20 \%$, and malnutrition by $61 \%[4]$.

It is crucial to reduce stunting as early as possible to avoid long-term adverse effects such as stunted child development [5]. Stunting affects brain development so that the child's intelligence level is not optimal. They are at risk of reducing productivity as an adult. Stunting also makes children more susceptible to disease [6], [7], [8]. Stunted children are at higher risk of developing chronic diseases in adulthood. Stunting and various forms of nutritional problems are estimated to contribute to the loss of $2-3 \%$ of gross domestic product (GDP) each year [9].
The problem of stunting can have an impact on health as well as impacts on the economy. The health impacts are failure to thrive (low birth weight, small, short, and underweight), stunted children as adults, susceptible to attacks from non-communicable diseases such as heart disease, stroke, diabetes, or kidney failure; inhibits the demographic bonus in Indonesia where the ratio of the unemployed to the working age population decreases; the threat of reduced intelligence level by $5-11$ points [10]. The long-term impact of stunting is Impairment of cognitive and motor development and metabolic disorders in adulthood risk non-communicable diseases (diabetes, obesity, stroke, and heart disease). The economic impact based on the research results by Brigitte et al. (2016) describes the average economic loss in 32 provinces in Indonesia of around IDR 96 billion-IDR 430 billion $(0.15-0.67 \%)$ of the average provincial GRDP in Indonesia. Due to decreased productivity due to stunting, potential economic losses are around IDR 3057 billion-IDR 13,758 billion (0.04-0.16\%) of Indonesia's total GDP [11].

The problem of malnutrition in Central Sulawesi Province based on Riskesdas (basic health 
research) results was still above the national average. The stunting rate for children aged 0-23 months in Sigi district was 1199 children or $20.2 \%$, and children aged $0-59$ months were 3580 or $24.7 \%$ of children with short and very short status (2019) [12]. Whereas in the village of West Sibalaya (stunting locus village), data of 2019 showed that from 50 children, 26 children were very short and stunting ( $52.1 \%$ stunted). It shows that the stunting rate in the village of West Sibalaya was still high in Sigi district during the coronavirus disease 2019 (COVID-19) pandemic.

To reduce stunting children in Sigi district, the regent then made a regent decree number: 444-185 of 2020, 10 villages were designated as focus locations (LOCUS) for the acceleration of stunting reduction in 2021, namely, Lemosiranindi, Pelempea, Morui, Marena, Siwongi villages, Rantewulu, Waturalele, Langko, South Sibalaya, and West Sibalaya. In the $1^{\text {st }}$ year, Sigi district, as a stunting locus district, has carried out actions 1-7.

In this pandemic, nutrition interventions are still being carried out in the stunting locus, sensitive nutrition interventions, and specific nutrition interventions. However, several implementation challenges are the absence of a strategy to accelerate the stunting prevention of pandemic, crisis, and disaster situations.

This study aims to determine the relationship between specific and sensitive nutritional interventions with children's nutritional status under five in the village of West Sibalaya, a stunting locus village, during the COVID-19 pandemic.

\section{Methods}

This type of research was a descriptive analytic study with a cross-sectional research design. This research was conducted in October 2020-November 2020 in the village of West Sibalaya, a stunting locus village in Sigi district. The population of this research is 35 mothers who have children under five in West Sibalaya Village, the Kamathipura Community Health Center, in 2020. The sample in this study was the entire population (total sampling) of 35 mothers.

The research variables are as follows:

1. The dependent variable in this study was nutritional status. The nutritional status of a child was showing a state of balance in the form of variable body weight according to age (BW/A), height or body length according to age $(\mathrm{BH} / \mathrm{A})$, and weight according to body length or height $(\mathrm{BW} / \mathrm{BH})$

2. Independent variables were specific and sensitive nutrition interventions. The specific nutritional intervention model was a direct activity to overcome stunting, such as food intake, infection, maternal nutritional status, infectious diseases, and environmental health. The supplemental feeding sector generally provided this specific model of intervention. Sensitive nutrition interventions were indirect efforts made to prevent and reduce nutritional problems (stunting). These activities were generally carried out by the non-health sector, including providing clean water, poverty reduction activities, and women empowerment.

This study used the Chi-square test with a significance level of $p<0.05$ with SPSS computer software.

\section{Results}

\section{Respondent characteristics}

Table 1 shows that of the 35 respondents, $45.7 \%$ were young adults (21-30 years), and $11.4 \%$ were young (<20 years). The majority of respondents had low education, $51 \%$ primary school and $40 \%$ junior high school. As for the number of children or parietal, most of the respondents had enough children, 1-2 people.

Table 1: The characteristics of the respondents

\begin{tabular}{lll}
\hline Characteristics of the respondents & $\mathrm{n}$ & $\%$ \\
\hline Age of respondent & & \\
$\quad<20$ years & 4 & 11.4 \\
$21-30$ years & 16 & 45.7 \\
$\quad>30$ years & 15 & 42.9 \\
Education & & \\
$\quad$ Elementary school & 18 & 51.4 \\
$\quad$ Junior high school & 14 & 40.0 \\
$\quad$ Senior high school & 3 & 8.6 \\
Parietal & & \\
$\quad<2$ & 24 & 68.6 \\
$\geq 2$ & 11 & 31.4 \\
\hline
\end{tabular}

\section{The nutritional status of the respondent's}

\section{child}

Table 2 shows that out of 35 children under five, whose nutritional status based on the BW/A index was still children who very underweight and underweight $(63.8 \%)$. Based on $\mathrm{BH} / \mathrm{A}$, there were still children who

Table 2: Children nutritional status based on the anthropometric index

\begin{tabular}{lll}
\hline Nutritional status category & $\mathrm{n}$ & $\%$ \\
\hline Weight for age & & \\
$\quad$ Severely underweight & 2 & 5.7 \\
$\quad$ Moderately underweight & 20 & 57.1 \\
$\quad$ Normal & 13 & 37.1 \\
Body length or height for age & 2 & 5.7 \\
$\quad$ Severely stunted & 8 & 22.9 \\
$\quad$ Stunted & 25 & 71.4 \\
$\quad$ Normal & & \\
Height or body length for body weight & 6 & 17.1 \\
$\quad$ Severely wasted & 14 & 40.0 \\
Wasted & 15 & 42.9 \\
$\quad$ Normal & & \\
\hline
\end{tabular}


very short and short (28.6\% stunting). Based on the BW/ $\mathrm{BH}$ index, there were still toddlers with $17.1 \%$ severe malnutrition and $40.0 \%$ malnutrition.

\section{Relationship between specific nutritional interventions and nutritional status}

Table 3 shows that out of 35 children under five, $63.2 \%$ of children with specific nutritional interventions were not good enough and lack nutritional status (based on body weight/age). However, $62.5 \%$ of children with the specific nutritional interventions were good, but their nutritional status was not good. Based on the results of bivariate analysis for specific nutrition interventions with body weight/age, the results obtained were $p=0.98$ $(p>0.05)$. It indicated that there was no relationship between specific interventions and nutritional status of body weight/age. Likewise, with $\mathrm{BH} / \mathrm{A}$ results obtained $p>0.668(P>0.05)$ and $B W / B H$ results obtained $p$ $=0.968$, which indicated no significant relationship between specific nutritional interventions and nutritional status.

Table 3: Specific nutritional interventions and nutritional status

\begin{tabular}{|c|c|c|c|c|c|c|c|}
\hline \multirow{3}{*}{$\begin{array}{l}\text { Specific nutrition } \\
\text { interventions }\end{array}$} & \multicolumn{4}{|c|}{ Weight for age } & \multirow{2}{*}{\multicolumn{2}{|c|}{ Total }} & \multirow[t]{3}{*}{$\mathrm{p}$-value } \\
\hline & \multicolumn{2}{|c|}{ Bad } & \multicolumn{2}{|c|}{ Good } & & & \\
\hline & $\mathrm{n}$ & $\%$ & $\mathrm{n}$ & $\%$ & $\bar{n}$ & $\%$ & \\
\hline Bad & 12 & 63.2 & 7 & 36.8 & 19 & 100 & 0.968 \\
\hline Good & 10 & 62.5 & 6 & 37.5 & 16 & 100 & \\
\hline Total & 22 & 62.9 & 13 & 37.1 & 35 & 100 & \\
\hline \multirow{3}{*}{$\begin{array}{l}\text { Specific nutrition } \\
\text { interventions }\end{array}$} & \multicolumn{4}{|c|}{ Body length or height for age } & \multirow{2}{*}{\multicolumn{2}{|c|}{ Total }} & $p$-value \\
\hline & \multicolumn{2}{|c|}{ Stunting } & \multicolumn{2}{|c|}{ Normal } & & & \\
\hline & $\mathrm{n}$ & $\%$ & $n$ & $\%$ & $\mathrm{n}$ & $\%$ & \\
\hline Bad & 6 & 31.6 & 13 & 68.4 & 19 & 100 & 0.668 \\
\hline Good & 4 & 62.5 & 12 & 37.5 & 16 & 100 & \\
\hline Total & 10 & 28.6 & 25 & 71.4 & 35 & 100 & \\
\hline \multirow{3}{*}{$\begin{array}{l}\text { Specific nutrition } \\
\text { interventions }\end{array}$} & \multicolumn{4}{|c|}{ Height or body length for body weight } & \multirow{2}{*}{\multicolumn{2}{|c|}{ Total }} & p-value \\
\hline & \multicolumn{2}{|c|}{$\mathrm{Bad}$} & \multicolumn{2}{|c|}{ Good } & & & \\
\hline & $\mathrm{n}$ & $\%$ & $\mathrm{n}$ & $\%$ & $\mathrm{n}$ & $\%$ & \\
\hline Bad & 10 & 52.6 & 9 & 47.4 & 19 & 100 & 0.968 \\
\hline Good & 10 & 62.5 & 6 & 37.5 & 16 & 100 & \\
\hline Total & 20 & 62.9 & 15 & 37.1 & 35 & 100 & \\
\hline
\end{tabular}

\section{The relationship between sensitive nutrition interventions and nutritional status}

Table 4 shows no relationship between sensitive interventions and children's nutritional status because most of them had been well implemented. However, there were still children who were malnourished.

Table 4: Nutrition sensitive interventions and nutritional status

\begin{tabular}{|c|c|c|c|c|c|c|c|}
\hline \multirow{3}{*}{$\begin{array}{l}\text { Nutrition sensitive } \\
\text { interventions }\end{array}$} & \multicolumn{4}{|c|}{ Weight for age } & \multirow{2}{*}{\multicolumn{2}{|c|}{ Total }} & \multirow[t]{3}{*}{$p$-value } \\
\hline & \multicolumn{2}{|c|}{ Bad } & \multicolumn{2}{|c|}{ Good } & & & \\
\hline & $\mathrm{n}$ & $\%$ & $\mathrm{n}$ & $\%$ & $\mathrm{n}$ & $\%$ & \\
\hline Bad & 3 & 60.0 & 2 & 40.0 & 5 & 100 & 1.000 \\
\hline Good & 19 & 63.3 & 11 & 36.7 & 30 & 100 & \\
\hline Total & 22 & 62.9 & 13 & 37.1 & 35 & 100 & \\
\hline \multirow{3}{*}{$\begin{array}{l}\text { Nutrition sensitive } \\
\text { interventions }\end{array}$} & \multicolumn{4}{|c|}{ Body length or height for age } & \multirow{2}{*}{\multicolumn{2}{|c|}{ Total }} & $p$-value \\
\hline & \multicolumn{2}{|c|}{ Stunting } & \multicolumn{2}{|c|}{ Normal } & & & \\
\hline & $\mathrm{n}$ & $\%$ & $\mathrm{n}$ & $\%$ & $\mathrm{n}$ & $\%$ & \\
\hline $\mathrm{Bad}$ & 1 & 60.0 & 4 & 40.0 & 5 & 100 & 1.000 \\
\hline Good & 9 & 63.3 & 21 & 36.7 & 30 & 100 & \\
\hline Total & 10 & 28.6 & 25 & 71.4 & 35 & 100 & \\
\hline \multirow{3}{*}{$\begin{array}{l}\text { Nutrition sensitive } \\
\text { interventions }\end{array}$} & \multicolumn{4}{|c|}{ Height or body length for body weight } & \multirow{2}{*}{\multicolumn{2}{|c|}{ Total }} & $\mathrm{p}$-value \\
\hline & \multicolumn{2}{|c|}{ Bad } & \multicolumn{2}{|c|}{ Good } & & & \\
\hline & $\mathrm{n}$ & $\%$ & $\mathrm{n}$ & $\%$ & $\mathrm{n}$ & $\%$ & \\
\hline Bad & 2 & 40.0 & 3 & 60.0 & 5 & 100 & 1.000 \\
\hline Good & 18 & 60.0 & 12 & 40.0 & 30 & 100 & \\
\hline Total & 20 & 62.9 & 15 & 37.1 & 35 & 100 & \\
\hline
\end{tabular}

The bivariate analysis results showed that specific nutritional interventions had no significant relationship with nutritional status $(p>0.05)$ as well as sensitive nutrition interventions with nutritional status had no significant relationship ( $p>0.05)$.

\section{Discussion}

During the COVID-19 pandemic, posyandu (Integrated Healthcare Center) activities were still running but not maximally because border residents visited Posyandu as well as officers. It is recognized that effective interventions are urgently needed to reduce stunting and need to be implemented on a sufficient scale, about a quarter in the short term. Specific interventions that have the most significant potential to reduce the morbidity and mortality burden for children are counseling about breastfeeding and fortification or supplementation of Vitamin A and zinc. Substantially, increasing complementary feeding through strategies such as nutrition education and nutritional counseling and dietary supplements in food insecure areas can reduce stunting and disease-related burdens [13], [14]. For sensitive (long term) stunting reduction interventions, it must be complemented by improvements in determinants of nutrition such as poverty, low education, disease burden, and a lack of women's empowerment [14], [15].

UNICEF's conceptual framework shows that nutritional problems are caused by direct causes, indirect causes, and root causes [3]. Overcoming this nutritional problem requires cross-sectoral cooperation through specific and sensitive nutrition intervention efforts [13]. The first 1000 days of life movement also uses specific nutrition interventions and sensitive nutrition. It is believed that sensitive nutrition interventions contribute $70 \%$ and specific nutrition interventions contribute $30 \%$ in overcoming nutritional problems [16].

Maternal education, family income, and maternal knowledge about nutrition are related to the incidence of stunting in children under five between rural and urban areas [17]. Addressing malnutrition in children requires an integrated approach that can improve the overall socioeconomic well-being of the family, mother's education, and knowledge of optimal nutrition practices, along with adequate maternal nutrition [18]. The promotion of complementary feeding practices suitable for children is currently only partially implemented [19].

To overcome this problem, the role of government and village is significant. During the pandemic, the maximum role of village was marked by the village head's involvement as a policymaker, front guard, and the closest to the community to prevent stunting. The village head has budgeted for stunting 
prevention activities through funds sourced from the village fund, such as the activities of posyandu to prevent stunting, providing additional food, increasing cadres' capacity, providing clean water, and environmental sanitation is further strengthened [6].

Ten specific nutrition interventions have been proven globally (The Lancet Maternal and Child Nutrition Series) in 2013 as essential for overcoming malnutrition (The Lancet, 2013). Four further interventions are deemed necessary for specific nutrition interventions. Of the 14 interventions, only 9 are national programs, 2 interventions that are partially implemented, and 3 interventions that are not currently national policies. Specific nutrition interventions based on global evidence need to be reflected in the health sector's minimum service standards and implemented through complete nutrition services at the regional level. At least 10 essential nutrition interventions should be incorporated into national policies and guidelines and reflected in the full coverage of services provided at the local level [13], [19].

This research's weakness is that the research was carried out in the COVID-19 pandemic. Even though nutrition interventions were still carried out, sensitive nutrition interventions and specific nutrition interventions were still carried out. However, its implementation has several challenges: The absence of a strategy to accelerate stunting for a pandemic situation. The implementation has not been optimal due to limited meetings to avoid transmission of COVID-19. Even in providing extra feeding to stunting children, villages and health centers try to make bird-houses (feeding houses) for food distribution in stunting children.

\section{Conclusions}

The implementation of specific nutrition interventions has not been maximized, such as giving Taburia (micronutrient powder), which was not implemented. It was due to no procurement and no malnutrition management due to the COVID-19 pandemic. Hence, many programs did not run optimally. This study shows no relationship between specific and sensitive nutrition interventions with the nutritional status of children under five in the stunting locus village, West Sibalaya village.

\section{References}

1. Kemenkes RI. Situasi Balita Pendek (Stunting) di Indonesia. Indonesia: Kemenkes RI; 2018.
2. Ni'mah K, Nadhiroh SR. Factors related to stunting in toddlers. Med Gizi Indones. 2015;10(1):13-9. https://doi.org/10.33096/ woph.v1i5.98

3. UNICEF, State of the World's Children 2019: Children, Food and Nutrition; 2019.

4. Hastuti W. Specific nutrition interventions with nutritional assistance on the nutritional status of children under five in Bandung district, West Java province. JRKPDB. 2017;9(1):32. https://doi.org/10.34011/juriskesbdg.v9i1.58

5. Khosiah K, Muhardini S. Human resource development training (PSDM) for village officials and human development cadres throughout the Aikmel sub-district, Lombok regency (stunting and stunting prevention convergence). J Pendidikan Mandala. 2019;4(5):318-22. https://doi.org/10.36312/jupe.v4i5.985

6. Kemenkes RI. Cegah Stunting Itu Penting, Indonesia: Kemenkes $\mathrm{Rl} ; 2018$.

7. Sutarto $S$, Mayasari $D$, Indriyani $R$. Stunting, risk factors and prevention. J Agromed. 2018;5(1):540-5.

8. Yadika ADN, Berawi KN, Nasution SH. The effect of stunting on cognitive development and learning achievement. J Majority. 2019;8(2):273-82.

9. Kementrian PPN/Bappenas. Pedoman Pelaksanaan Intervensi Penurunan Stunting Terintegrasi di Kabupaten/Kota, Kementrian PPN/Bappenas; 2018.

10. Astuti S, Megawati G, Samson CM. Stunting Prevention Movement Through Community Empowerment in Jatinangor Sub-District, Sumedang District. Dharmakarya. 2018;7(3):1858. https://doi.org/10.24198/dharmakarya.v7i3.20034

11. Potential Economic Losses Due to Stunting in Toddlers in Indonesia in 2013. J Gizi Pangan. 2016;11(3):247-54. https:// doi.org/10.22146/ijen.22899

12. Ramadhan K. Height-for-Age Nutritional Status among Under 5 Years. Poltekita: JIK. 2020;13(2):96-101. https://doi. org/10.33860/jik.v13i2.38

13. Rosha BC, Sari K, Sp IY, Amaliah N, Utami NH. The Role of Specific and Sensitive Nutrition Interventions in Improving the Nutritional Problems of Toddlers in Bogor City. Bul Penelitian Kesehatan. 2016;44(2):127-38. https://doi.org/10.22435/bpk. v44i2.5456.127-138

14. Mitra M. The Problem of Short Children (Stunting) and Interventions to Prevent Stunting (A Literature Review). J Kesehatan Komunitas. 2015;2(6):254-61. https://doi. org/10.25311/jkk.vol2.iss6.85

15. Bhutta ZA, Ahmed T, Black RE, Cousens S, Dewey K, Giugliani E, et al. What works? Interventions for maternal and child undernutrition and survival. Lancet. 2008;371(9610):417-40. https://doi.org/10.1016/s0140-6736(07)61693-6 PMid:18206226

16. Sandjojo EP. Buku Saku Desa Dalam Penanganan Stunting Buku Saku Desa Dalam Penanganan Stunting; 2017. p. 42. https://doi.org/10.37341/interest.v6i2.94

17. Aridiyah FO, Rohmawati N, Ririanty M. The Factors Affecting Stunting on Toddlers in Rural and Urban Areas. Pustaka Kesehatan. 2015;3(1):8. https://doi.org/10.35892/jikd.v14i1.104

18. Osei A, Pandey P, Spiro D, Nielson J, Shrestha $R$, Talukder Z, et al. Household food insecurity and nutritional status of children aged 6 to 23 months in kailali district of Nepal. Food Nutr Bull. 2010;31(4):483-94. https://doi. org/10.1177/156482651003100402

19. Nisa LS. Kebijakan penanggulangan stunting di Indonesia. J Kebijakan Pembangunan. 2018;13(2):173-9. 